HANNA LEWANDOWSKA

Wyższa Szkoła Gospodarki Euroregionalnej

im. Alcide De Gasperi w Józefowie

hanna.lewandowska@wsge.edu.pl

ORCID iD: https://orcid.org/0000-0003-0362-8779

\title{
Nauczanie czy wychowanie? Rola nauczyciela we współczesnej szkole - oczekiwania rodziców
}

\section{Teaching or upbringing? \\ The role of a teacher in contemporary school - expectations of parents}

\section{STRESZCZENIE}

Artykuł jest próbą określenia wymagań oczekiwań rodziców uczniów wobec nauczycieli po trudnym okresie nauki zdalnej wymuszonym przez pandemię Covid-19. Podczas takiej formy edukacji opiekunowie mieli szansę obserwacji nauczyciela podczas jego pracy z dziećmi i dokonania oceny jej efektów. Mogli również porównywać metody i środki dydaktyczne stosowane przez różnych pedagogów.

Po okresie wymuszonej izolacji mogły się również zmienić wymagania rodziców odnośnie do wsparcia wychowawczego ich dzieci. Placówki oświatowe i sami nauczyciele stają więc przed niełatwym zadaniem pogodzenia funkcji edukatora i wychowawcy w jednym.

Przedstawione wyniki badań prezentują oczekiwania związane zarówno z przygotowaniem merytorycznym nauczyciela do wykonywania zawodu, jak i z posiadaną przez niego wiedzą z zakresu wsparcia pedagogicznego i terapeutycznego.

SŁowa KLUCzowe: oczekiwania wobec nauczycieli, edukacja w placówkach oświatowych, wychowanie w placówkach oświatowych, zadania nauczyciela. 


\section{SUMMARY}

The article is an attempt to define the expectations of parents of students towards teachers after a difficult period of remote learning forced by the Covid-19 pandemic. During this form of education, the tutors had a chance to observe the teacher while he is working with children and assessing its effects. They could also compare the teaching methods and aids used by different educators. After the period of forced isolation, the parents' requirements regarding the upbringing support of their children may also have changed. Educational institutions and teachers themselves face the difficult task of reconciling the functions of teacher's and educator in one.

The presented research results present the expectations related to the substantive preparation of the teacher for the profession and with his knowledge in the field of pedagogical and therapeutic support.

KEYwORDs: expectations towards teachers, education in educational institutions, upbringing in educational institutions, teacher's tasks.

\section{Wprowadzenie}

Artykuł niniejszy jest raportem $\mathrm{z}$ badań mających na celu poznanie aktualnych potrzeb rodziców uczniów w związku z edukacją i wychowaniem ich dzieci w placówce oświatowej. Czy dzięki edukacji zdalnej te oczekiwania się zmieniły? A jeśli tak, to w jaki sposób? Czy nauczyciele są w stanie sprostać wymaganiom uczniów i ich rodziców w zmieniającej się rzeczywistości? Czy według opiekunów uczniów konieczne jest dokształcanie się nauczycieli, a jeśli tak, to w jakim zakresie?

Po krótkiej charakterystyce podstawowych pojęć związanych z tematem pracy zaprezentowano część wyników badań dotyczących oczekiwań rodziców uczniów wobec nauczycieli. Badania te prowadzono wśród opiekunów dzieci w wieku od sześciu do osiemnastu lat, z podziałem na cztery etapy edukacyjne: zerówkę, klasy 1-3 szkoły podstawowej, klasy 4-8 szkoły podstawowej i szkoły ponadpodstawowe $\mathrm{z}$ racji specyfiki pracy pedagogicznej i znacznych różnic w podejściu do ucznia i jego potrzeb. Działalność współczesnej szkoły nie może być skierowana na uzyskanie "produktu standardowego" (Schulz, 1996, s. 18).

Dlatego obecnie w szkołach kładzie się nacisk na rozwijanie posiadanych przez uczniów uzdolnień. $Z$ powodzeniem funkcjonują koła 
zainteresowań i programy dostosowane do indywidualnych potrzeb dziecka, również dziecka zdolnego. Na tym jednak zadania placówki się nie kończą. W obliczu zmian współczesnego świata Polska szkoła zderza się z nowymi oczekiwaniami ze strony rodziców uczniów. Podczas nauki zdalnej włączyli się oni aktywnie w proces edukacyjny i niejednokrotnie stali się podstawowym nauczycielem własnego potomstwa. Z pewnością ma to wpływ na postrzeganie szkoły jako placówki edukacyjnej.

Jak wynika z badań prof. Ewy Wysockiej i Katarzyny Tomiczek z Uniwersytetu Śląskiego, jedynie 5,38\% ankietowanych uczniów (15 osób) pozytywnie ocenia funkcje wychowawcze szkoły, takie jak: zdobywanie nowych doświadczeń uczących (wychowujących) i świadomej refleksji nad własnym życiem (Wysocka, Tomiczek, 2014, s. 168-188) i sposobu wartościowania szkoły przez uczniów. Oznaczać to może zbyt małą rolę wychowawczą placówki w kształtowaniu młodych ludzi.

Dodatkowo w czasie pandemii Covid-19 uczniowie zostali zamknięci w domach, a ich kontakty $\mathrm{z}$ rówieśnikami były możliwe tylko $\mathrm{w}$ formie cyfrowej. Wiele mówi się o możliwych tego konsekwencjach dla ich rozwoju społecznego i procesu socjalizacji.

„Skutki długotrwałego nauczania zdalnego w szkołach czy na uczelniach są ogromne, zwłaszcza jeśli chodzi o zdrowie psychiczne. Wielu młodych ludzi już teraz potrzebuje pomocy terapeuty czy psychologa” (Znajmiecka, 2021).

Wobec powyższego troska nauczyciela o rozwój społeczny i emocjonalny ucznia staje się jeszcze pilniejsza. Być może rodzice uczniów będą spodziewać się od pedagogów większego wsparcia w tym zakresie. Niniejsze badania są więc nie tylko próbą sprecyzowania oczekiwań rodziców wobec nauczycieli, ale także określenia, czy są one spójne $\mathrm{z}$ wymaganiami stawianymi nauczycielom przez obowiązującą podstawę programową.

Dlatego też niezbędne jest poszukiwanie nowych strategii wychowania pozwalających na przygotowanie młodych ludzi do efektywnego funkcjonowania we współczesnym społeczeństwie" (Graca, Such-Pyrgiel, 2018, s.73-74). 


\section{Wychowanie w podstawie programowej}

Wychowanie to według definicji encyklopedycznej „wszelkie zjawiska związane $\mathrm{z}$ oddziaływaniem środowiska społecznego i przyrodniczego na człowieka, kształtujące jego tożsamość, osobowość, postawy; w znaczeniu węższym - oddziaływania organizowane celowo, mające prowadzić do pożądanych zmian w funkcjonowaniu jednostek i grup" (encyklopedia.pwn.pl, 2021). Termin ten wywodzi się od greckiego paideia. Początkowo był on rozumiany jako wykształcenie w zakresie umiejętności praktycznych, zawodowych, które umożliwiały dziecku funkcjonowanie w społeczeństwie, będąc jego cenną częścią. Jednak dopiero Platon opisał paideia jako proces polegający na formowaniu człowieka w oparciu o idealny obraz bytu trwający przez całe życie człowieka (Bremer, 1989, t. 7, s. 35-39).

K. Sośnicki wydzielił dwa typy oddziaływania wychowawczego, wskazując na zależności pomiędzy dążeniami własnymi człowieka a wpływem jego środowiska. Wychowanie humanistyczne jest bowiem według autora czynnością wykonywaną przez jednego człowieka wobec drugiego, a więc zakładającą planowe działanie zmierzające w określnym kierunku. Natomiast wychowanie liberalistyczne polega na naturalnym rozwoju człowieka opierającym się zarówno na motywacji wewnętrznej, jak i wpływie bodźców zewnętrznych. Takie oddziaływanie środowiska nie jest zamierzonym działaniem i nie występuje tu osoba wychowawcy kierująca procesem według własnego upodobania (Sośnicki, 1949, s. 24-26).

„Dzisiejsza młodzież lubi luksus, ma złe maniery, nie uznaje żadnych autorytetów i nie ma szacunku dla starszych. W naszych czasach dzieci stały się tyranami. Nie są posłuszne swoim rodzicom, zbyt szybko jedzą i tyranizują nauczycieli” - Sokrates (ok. 400 r. p.n.e.; Morbitzer, 2014).

Niniejsza wypowiedź Sokratesa pochodzi z 400 r. p.n.e. i dowodzi niezbicie, że młodzież zawsze sprawiała dorosłym trudności wychowawcze. Nie jest to więc kwestia czasów, w jakich żyjemy, ani wina postępu technicznego. Od wieków oczekiwaliśmy bowiem, że dzieci będą spełniały nasze wymagania. W czasach obecnych część odpowiedzialności za wychowanie młodych ludzi bierze na siebie placówka edukacyjna. 
Często służy rodzicom wsparciem w zakresie zajęć wspierających harmonijny rozwój uczniów, również w zakresie socjalizacji. Takie współczesne oddziaływanie autorzy B. Śliwerski i B. Milerski przedstawili jako: „całokształt procesów i oddziaływań zachodzących w toku wzajemnych relacji między dwiema osobami, pomagających im rozwijać własne człowieczeństwo" (Milerski, Śliwerski, 2000, s. 274).

Powyższa definicja znacznie zmienia dotychczasowe rozumienie procesu wychowania. Zakłada bowiem wzajemne wpływy dwóch osób oparte na zaufaniu i empatii. Takie wychowanie zakłada równorzędność ludzi biorących w nim udział.

Inni autorzy definiują proces wychowania, skupiając się na jego spodziewanych efektach: „wychowanie to proces wspomagania wychowanka w rozwoju, ukierunkowany na osiąganie przez niego pełnej dojrzałości w czterech sferach: fizycznej, psychicznej, społecznej i duchowej” (Gaś, 2006, s. 11).

Takie efekty często mierzone są w standaryzowanych arkuszach obserwacji, zwłaszcza w zerówce i młodszych klasach szkoły podstawowej, w których funkcjonuje ocena opisowa. Jednak w kolejnych latach edukacji nauczyciele stawiają coraz mniejszy nacisk na rozwój społeczny wychowanków, skupiając się mocniej na efektach edukacyjnych - testach, miejscach osiąganych w konkursach i ocenach uczniów. To jednak socjalizacja jest pierwszym aspektem wychowania dziecka i rozpoczyna się już w pierwszych dniach jego życia. Kontakt z najbliższą rodziną jest podstawą pierwszych relacji społecznych młodego człowieka. Ten wpływ środowiska zewnętrznego jest niezwykle ważny dla późniejszego procesu wychowania, gdyż według prof. Smetańskiego „w szerokim społecznym znaczeniu pod pojęciem wychowania należy rozumieć celowy wpływ na rozwój osobowości całego środowiska społecznego, które ją otacza: rodziny, instytucji oświatowo-wychowawczych, zespołów zawodowych, mediów itp." (Smetański, 2011, s. 171-183).

Najważniejszą jednak różnicą między procesami socjalizacji a wychowania jest intencjonalność niniejszego odziaływania. Wychowanie zawsze jest ukierunkowane na cel. Dlatego też na terenie placówki oświatowej zjawisko to może zostać zaplanowane w odpowiednich dokumentach. 
Dwoma podstawowymi dokumentami szkolnymi, określającymi jej działalność są: szkolny zestaw programów nauczania i program wychowawczo-profilaktyczny. Widać więc, że oddziaływanie placówki na uczniów z założenia jest dwojakie.

Placówka oświatowa nie ogranicza się jednak do procesu rozwijania kompetencji społecznych swoich uczniów. Jej oddziaływania są znacznie głębsze, odnoszą się bowiem do człowieczeństwa dziecka poprzez formowanie jego systemu wartości moralnych mających wpływ również na jego dorosłe życie. Podstawa programowa zakłada również kształtowanie postaw obywatelskich i patriotycznych swoich uczniów. $\mathrm{Na}$ terenie placówek często organizowane są uroczystości o charakterze patriotycznym, konkursy mające na celu rozbudzanie świadomości obywatelskiej i akcje promujące dbałość o ojczyznę i przywiązanie do kraju. W programie zajęć historii umieszczono również tradycje narodowe, a uczniowie zachęcani są do ich kultywowania.

Kolejną kwestią wyznaczoną przez podstawę programową jest rozwijanie wrażliwości uczniów na piękno otaczającej przyrody, jak również zachęcanie ich do podejmowania działań na rzecz środowiska. Wiele placówek organizuje obchody Dnia Ziemi, uświadamiając dzieci od najwcześniejszych roczników o zagrożeniach związanych z nadmiernym wykorzystywaniem surowców. Treści związane z ekologią są również wdrażane podczas lekcji nauczania zintegrowanego w klasach 1-3 i w klasach starszych na lekcjach przyrody, biologii i geografii.

Uczniowie są również zachęcani do angażowania się w rozwój otoczenia szkolnego i lokalnego, w tym do włączania się w wolontariat. Szkoła dba też o wychowanie dzieci i młodzieży w duchu akceptacji i szacunku dla drugiego człowieka.

„Działalność wychowawcza szkoły należy do podstawowych celów polityki oświatowej państwa. Wychowanie młodego pokolenia jest zadaniem rodziny i szkoły, która w swojej działalności musi uwzględniać wolę rodziców, ale także i państwa, do którego obowiązków należy stwarzanie właściwych warunków wychowania. Zadaniem szkoły jest ukierunkowanie procesu wychowawczego na wartości, które wyznaczają cele wychowania i kryteria jego oceny" (Dz.U. 2017, poz. 356, s. 15). 


\section{Edukacja w podstawie programowej}

Edukowanie uczniów jest bez wątpienia równie ważnym jak ich wychowywanie zadaniem szkoły. Podstawa programowa zakłada, że głównym celem edukacji jest wspieranie całościowego rozwoju dziecka. W pierwszym etapie, czyli klasach 1-3, program skupia się na zaspokajaniu naturalnych potrzeb ucznia. W zajęciach wykorzystywana jest więc naturalna, dziecięca ciekawość świata, na której budowana jest wiedza ucznia. Zadaniami szkoły na tym etapie określonymi przez podstawę programową są m.in. wspieranie wielokierunkowej aktywności dziecka, umożliwianie mu zdobywania własnych doświadczeń na drodze prowadzenia samodzielnych eksperymentów; stymulowanie rozwoju ucznia we wszystkich obszarach: fizycznym, emocjonalnym, społecznym i poznawczym; organizowanie uczniom zarówno czasu przeznaczonego na naukę, jak i odpoczynek oraz dostosowanie go do indywidualnych potrzeb dziecka; opracowanie oraz realizowanie programu nauczania $z$ poszanowaniem godności uczniów czy zapewnienie im dostępu do wiarygodnych źródeł informacji i nowoczesnych technologii.

Zajęcia prowadzone w szkole powinny być dostosowane do indywidualnych intelektualnych potrzeb i oczekiwań rozwojowych dzieci. Powinny zapewniać zdobywanie nowych doświadczeń na drodze aktywizacji uczniów i wywoływania ich zaciekawienia.

Placówka oświatowa powinna być dostosowana do potrzeb uczniów, zapewniać ergonomię i bezpieczeństwo podczas przebywania dzieci w budynku. Wnętrza sal powinny być urządzone w sposób stymulujący systematyczny rozwój wrażliwości estetycznej i poczucia tożsamości.

Cele kształcenia edukacji wczesnoszkolnej precyzowane są w odniesieniu do czterech podstawowych obszarów rozwojowych dziecka: fizycznego, emocjonalnego, społecznego i poznawczego. Również na ich bazie przeprowadzana jest ewaluacja dotychczasowych działań i diagnoza aktualnych potrzeb uczniów. Cele edukacyjne uczniowie klas początkowych osiągają dzięki rozwijaniu prostych czynności praktycznych i intelektualnych w czynności bardziej złożone. 
Na drugim etapie edukacyjnym podstawa programowa podobnie określa cele kształcenia. Głównym zadaniem nauczycieli jest rozwijanie kompetencji i umiejętności wychowanków poprzez pogłębianie ich wiedzy. Uczniowie realizujący drugi etap edukacyjny pod wpływem zajęć w placówce rozwijają swoją kreatywność, innowacyjność i przedsiębiorczość. Uczą się logicznego myślenia, dostrzegania związków przyczynowo-skutkowych, samodzielnego wyciągania wniosków i argumentowania. Nauczyciel powinien rozbudzać ciekawość poznawczą swoich podopiecznych i wzmagać ich motywację do nauki. Rolą szkoły jest „wyposażać uczniów w taki zasób wiadomości oraz kształtowanie takich umiejętności, które pozwalają w sposób bardziej dojrzały i uporządkowany zrozumieć świat” (Dz.U. 2017, poz. 356, s. 76). W starszych klasach szkoły podstawowej placówka wspiera swych podopiecznych w rozpoznawaniu własnych predyspozycji i określaniu drogi dalszej edukacji. „Ważną rolę w kształceniu i wychowaniu uczniów w szkole podstawowej odgrywa edukacja zdrowotna. Zadaniem szkoły jest kształtowanie postaw prozdrowotnych uczniów, w tym wdrożenie ich do zachowań higienicznych, bezpiecznych dla zdrowia własnego i innych osób, a ponadto ugruntowanie wiedzy z zakresu prawidłowego odżywiania się, korzyści płynących z aktywności fizycznej, a także stosowania profilaktyki” (Dz.U. 2017, poz. 356, s. 187).

Cele nauczania przekładają się bezpośrednio na działalność każdego pedagoga. W zależności od nich nauczyciel precyzuje treści nauczania, ujmując je w planie działalności edukacyjnej, dopasowuje do nich metody i środki dydaktyczne oraz formy nauczania. To w połączeniu z działalnością wychowanków przekłada się na wyniki nauczania.

Zarówno szkolny zestaw programów nauczania, jak i program wychowawczo-profilaktyczny szkoły tworzą spójną całość i muszą uwzględniać wszystkie wymagania opisane w podstawie programowej. Ich przygotowanie i realizacja są zadaniami zarówno całej szkoły, jak i każdego nauczyciela i wychowawcy klasy. 


\section{Oczekiwania rodziców uczniów wobec nauczycieli}

W badaniu precyzującym oczekiwania opiekunów uczniów wobec ich nauczycieli udział wzięło 81 rodziców dzieci, które uczęszczają do przedszkola/klasy zerowej (15\%), klas edukacji początkowej (33\%), klas drugiego etapu edukacyjnego (44\%) i szkół ponadpodstawowych (7\%). Choć oczekiwania opiekunów na poszczególnych etapach edukacyjnych mogą się różnić, to jednak edukowanie i wychowywanie pozostaje fundamentem działalności każdej placówki oświatowej.

Rodziców uczniów zapytano, czy oczekują, by nauczyciel oprócz koniecznego wykształcenia do zawodu posiadał dodatkowe kwalifikacje. Większość ankietowanych, bo aż 68 osób (47\%), odpowiedziała, że owszem, oczekuje, by nauczyciel posiadał dodatkowe kompetencje potwierdzone dyplomem ukończenia studiów podyplomowych lub certyfikatem ukończenia kursu z zakresu przygotowania pedagogicznego lub terapeutycznego. Dwudziestu pięciu (31\%) badanych nie oczekuje od nauczycieli posiadania żadnych dodatkowych kwalifikacji, a 18 (22\%) liczy, że nauczyciel ich dziecka będzie posiadał dodatkowe kwalifikacje potwierdzone dyplomem ukończenia studiów podyplomowych lub certyfikatem ukończenia kursu poszerzającego jego przygotowanie merytoryczne do nauczania. Powyższe dane przedstawiono na wykresie 1.

Wykres 1.

Oczekiwania opiekunów uczniów wobec wykształcenia nauczycieli

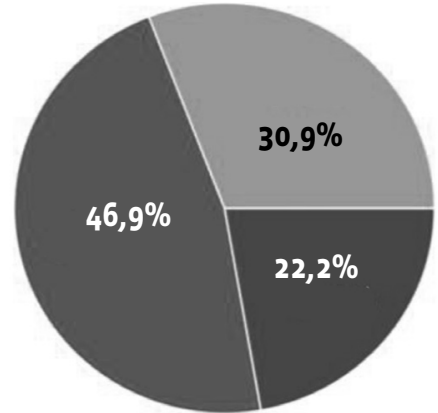

Źródło: Badania własne
Tak, oczekuję, że nauczyciel będzie posiadał dyplom ukończenia studiów podyplomowych lub kursów uzupełniających jego przygotowanie merytoryczne

Tak, oczekuję, że nauczyciel będzie posiadał dyplom ukończenia studiów podyplomowych lub kursów uzupełniających jego przygotowanie Nie oczekuję od nauczyciela posiadania dodatkowych kwalifikacji 
Zdecydowana większość respondentów potwierdziła, że oczekuje od nauczyciela, by rozpoczynając rok szkolny, przedstawił im planowany program nauczania i zakres wymagań edukacyjnych. Takiej odpowiedzi udzieliły 72 osoby (89\%).

Również prawie wszyscy badani oczekują od nauczyciela przedstawienia przedmiotowego systemu oceniania. Tak odpowiedziało 79 osób (97\%).

Prawie równie zgodni byli ankietowani przy odpowiedzi na pytanie o oczekiwanie od nauczyciela posiadania dodatkowych kompetencji cyfrowych i włączania w prowadzone zajęcia nowoczesnych technologii. Takich kwalifikacji spodziewa się 70 badanych, co stanowi $86 \%$. Te dane przedstawiono na wykresie 2 .

Wykres 2.

Oczekiwania opiekunów uczniów wobec kompetencji cyfrowych nauczycieli

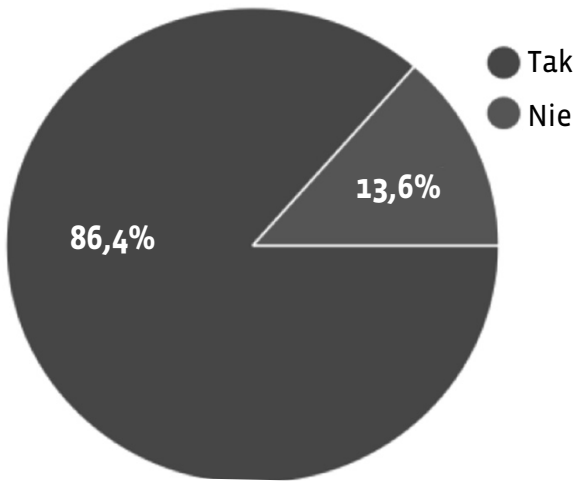

Źródło: Badania własne

Większość respondentów oczekuje jednak od wychowawcy klasy, że będzie on znał sytuację rodzinną każdego swego ucznia. Tak odpowiedziało pięćdziesiąt jeden osób (65\%).

Zdecydowana większość ankietowanych potwierdziła, że oczekuje od wychowawcy klasy wsparcia wychowawczego. Takiej odpowiedzi udzieliło aż siedemdziesięciu jeden (88\%) ankietowanych. Te wyniki zobrazowano na wykresie 3. 
Wykres 3.

Oczekiwania opiekunów uczniów wobec wsparcia wychowawczego ze strony nauczycieli

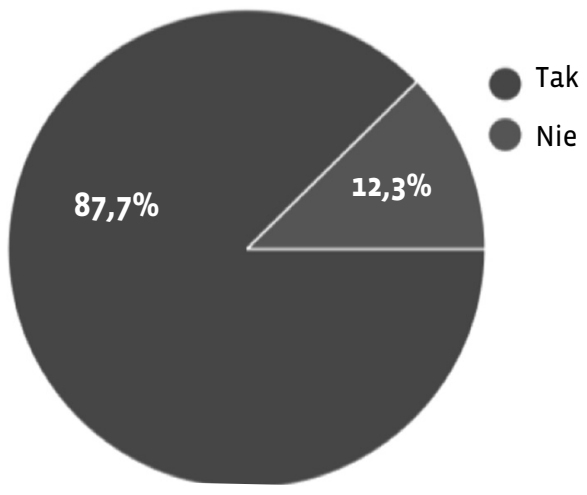

Źródło: Badania własne

Nie jest więc też zaskoczeniem, że aż 65 (80\%) badanych oczekuje od nauczyciela prowadzenia w klasie systemu motywacyjnego będącego narzędziem oddziaływania wychowawczego.

Opinie ankietowanych były znacznie bardziej podzielone przy pytaniu, czy oczekują od nauczyciela ustalenia wspólnego dla placówki i domu rodzinnego systemu wychowawczego. Przecząco odpowiedziała większość badanych, czyli 42 osoby, co stanowi 52\%. Przeważająca większość respondentów jest zadowolona $\mathrm{z}$ dotychczasowej współpracy z wychowawcą klasy. Takiej odpowiedzi udzieliły aż 62 osoby (76\%). Oznacza to też niestety, że 19 (23\%) rodziców nie jest zadowolonych i należałoby zdiagnozować źródło i rodzaj trudności, z którymi się borykają, by usprawnić współpracę na linii dom rodzinny - placówka oświatowa.

Ankietowanych zapytano również, co ich zdaniem jest nadrzędną funkcją nauczyciela w szkole: edukowanie czy wychowanie? W tym pytaniu respondenci również byli dość zgodni, gdyż aż 71 osób (88\%) odpowiedziało, że edukowanie. Jest to o tyle ciekawe, że również większość badanych oczekuje od szkoły wsparcia wychowawczego i chce, by wychowawca klasy znał sytuację rodzinną każdego ucznia. 


\section{Podsumowanie}

Złożona rzeczywistość społeczno-polityczna, ale i wychowawczo-socjologiczna powoduje wiele aberracji i problemów w organizowaniu realizowania procesów wychowawczych, zwłaszcza w odniesieniu do młodzieży (Graca, Such-Pyrgiel, 2018, s. 83).

Przeprowadzone badania wykazały, że rodzice uczniów z pewnością oczekują od nauczycieli wsparcia wychowawczego. Choć podstawa programowa w równym stopniu stawia nacisk na rozwój dziecka w zakresie poznawczym, emocjonalnym i społecznym, wydaje się, że w tym szczególnym, popandemicznym czasie opiekunowie przywiązują dużą wagę do zaangażowania nauczyciela w pozaszkolne funkcjonowanie uczniów. Jednocześnie liczą na to, że rozpoczynając nowy rok szkolny, nauczyciel przedstawi planowany program, wymagania edukacyjne i przedmiotowy system nauczania.

W czasie nauki na odległość rodzice często pomagali dzieciom w nauce, sami stając się głównym nauczycielem ucznia. W wielu przypadkach w naukę swoich dzieci zaangażowali się również ci opiekunowie, którzy do tej pory tego nie robili. Być może stąd wynika chęć poznania jasno określonych oczekiwań nauczycieli.

Rodzice oczekują od nauczycieli również posiadania kompetencji cyfrowych, które umożliwiają prowadzenie ciekawszych zajęć i wdrażanie uczniów w korzystanie z nowoczesnych technologii. W dzisiejszych realiach wydaje się to nieodzowne, zwłaszcza podczas nauki zdalnej.

Wielu opiekunów chciałoby, aby nauczyciel uczący ich dziecko posiadał dodatkowe kompetencje $\mathrm{w}$ zakresie przygotowania pedagogicznego lub terapeutycznego, co również wskazuje na potrzebę wsparcia wychowawczego przez placówkę oświatową.

Funkcja edukacyjna i wychowawcza nauczyciela przeplatają się ze sobą i są nierozerwalnie złączone. Do ich umiejętnego łączenia i dopasowywania do indywidualnych potrzeb uczniów lub specyfiki rzeczywistości szkolnej niezbędne są kompetencje nauczyciela z zakresu empatii i komunikacji. Niezwykle ważna jest w tej kwestii współpraca ze środowiskiem rodzinnym ucznia. Planując kolejne zajęcia, warto wziąć pod uwagę oczekiwania rodziców naszych podopiecznych. 


\section{Bibliografia}

Berner H. (2006). Współczesne kierunki pedagogiczne. W: Pedagogika. Podstawy nauk o wychowaniu, t. 1, B. Śliwerski (red.). Gdańsk, GWP, s. 203-211

Bremer D. (1989). Paideia. W: J. Ritter, K. Gründer. (red), Historisches Wörterbuch der Philosophie, t. 7. Basel-Stuttgart: Schwabe, s. 35-39

Brezinka W. (2005). W dobie przemian kulturowych, Kraków, Wydawnictwo WAM, s. 21-35

Denek K. (1999). Reforma systemu edukacji. Nadzieje i wątpliwości. W: K. Denek, T.M. Zimny (red.). Edukacja Jutra. V Tatrzańskie Seminarium Naukowe. Częstochowa, s. 12-21

Dąbkowska M. (2021). Psychospołeczne konsekwencje pandemii koronawirusa (Covid-19) u dzieci i młodzieży - przeglad wybranych opracowań. Gdańsk: Uniwersytet Gdański, s. 150-160

Gaś Z.B. (2006). Profilaktyka w szkole. Warszawa: WSiP, s. 11

Górniewicz J. (2008). Teoria wychowania (wybrane problemy). Olsztyn: Olsztyńska Szkoła Wyższa im. Józefa Rusieckiego, s. 187

Graca T., Such-Pyrgiel M. (2018). Nowe problemy oddziatywań wychowawcz $y c h w$ kontekście zjawisk pojawiających się $w$ okresie ponowoczesności, W: J. Wyleżałek, M. Such-Pyrgiel (red.). Szkice pedagogiczne. Dylematy juwentologii, Wyd. WSGE, Józefów s. 73-74

Graca T., Such-Pyrgiel M. (2018). Nowe problemy oddziaływań wychowawczych $w$ kontekście zjawisk pojawiających się $w$ okresie ponowoczesności, W: J. Wyleżałek, M. Such-Pyrgiel (red.). Szkice pedagogiczne. Dylematy juwentologii, Wyd. WSGE, Józefów s. 83

Juul J. (2014). Kryzys szkoły. Co możemy zrobić dla uczniów, nauczycieli i rodziców?. Podkowa Leśna: Wydawnictwo MIND, s. 109

Katra G. (2019). Wspótczesne ujęcia i modele wychowania, Psychologia Wychowawcza nr 16/2019, s. 27-48

Konarzewski K. (1987). Podstawy teorii oddziaływań wychowawczych. Warszawa: PWN, s. 5-23

Kujawiński J. (2010). Ewolucja szkoły i jej wspótczesna wizja. Poznań: Wydawnictwo Naukowe UAM, s. 48-90

Kwatera A. (2015). Zróżnicowania szkoty: wielość modeli i ofert systemu edukacyjnego - alternatywa dla tradycji. W: S. Kowal, M. Mądry-Kupiec (red.), Przygotowanie do wykonywania zawodu nauczyciela: $w$ stronę edukacji spersonalizowanej. Będzin: Wydawnictwo internetowe e-bookowo, s. 199-218 
Łobocki M. (2003). Teoria wychowania w zarysie. Kraków: Wydawnictwo IMPULS, s. 29-51

Łobocki M. (2007). W trosce o wychowanie w szkole, Kraków, Oficyna Wydawnicza Impuls, s. 97-132

Milerski B., Śliwerski B. (2000) (red.). Pedagogika. Warszawa: PWN, s. 155-176

Muszyński H. (1976). Zarys teorii wychowania. Warszawa: PWN, s. 224-230

Paszkiewicz A. (1998). Technologia wychowania. Białystok: Wyd. UWB, s. 9-61

Piecuch E. (2012). Wychowanie szczęśliwego człowieka podstawowym celem rodziców. Wrocław: Uniwersytet Wrocławski, s. 63-81

Przyborowska B. (2013). Pedagogika innowacyjności. Między teoriq a praktyką. Torun: Wydawnictwo Naukowe UMK, s. 29-30

Salamucha A. (2004). Definicje wychowania $w$ literaturze pedagogicznej, Rocznik Nauk Społecznych, Tom XXXII, zeszyt 2, s. 31-41

Schulz R. (1996). Studia z innowatyki pedagogicznej. Toruń: Wydawnictwo Naukowe UMK, s. 73-80

Smetański M. (2011). Charakterystyka wychowania jako procesu pedagogicznego. Warszawa: Kultura i Wychowanie 1, 171-183

Smykowska D. (2008). Wspótpraca szkoły $z$ rodzina $w$ zaspokajaniu potrzeb rozwojowych dzieci z lekkim upośledzeniem umysłowym. Kraków: Oficyna Wydawnicza Impuls, s. 15 - 27

Sośnicki K. (1959). Dydaktyka ogólna. Wrocław: Zakład Narodowy im. Ossolińskich, s. 197-221

Śliwerski B. (2001). Współczesne teorie i nurty wychowania. Kraków: IMPULS, s. $96-103$

Tchorzewski A.M. (2018). Wstęp do teorii wychowania. Kraków: Wydawnictwo Naukowe Akademii Ignatianum, s. 53-77

Tyrała P. (2011). Teoria wychowania. Blizej uniwersalnych wartości i realnego życia. Toruń: Wyd. Adam Marszałek, s. 127-134

Winiarski M. (1993). Współdziałanie szkoły i rodziny. Realia i możliwości, Problemy Opiekuńczo-Wychowawcze nr 5, s. 207-210

Wołoszyn S. (1992). Nauki o wychowaniu w Polsce w XX wieku. Warszawa: Instytut Badań Edukacyjnych, s. 22-28

Wysocka E., Tomiczek K. (2014). Szkoła jako środowisko życia i codzienność ucznia - analiza teoretyczna i empiryczne egzemplifikacje percepcji, Uniwersytet Śląski w Katowicach, Przegląd Pedagogiczny nr 1/2014, s. 22-28

Zarzecki L. (2012). Teoretyczne podstawy wychowania. Teoria i praktyka w zarysie. Karkonoska Jelenia Góra, Państwowa Szkoła Wyższa, s. 25-33 


\section{Netografia}

Bralczyk J. (red) Wychowanie. W: Bralczyk J. (2005). Słownik 100 tysięcy potrzebnych słów, wyd. I, Warszawa, https://encyklopedia.pwn.pl/haslo/wychowanie;3998683.html (dostęp: 12.04.2021)

Mikołajczak M. (2015). Polska szkoła - czy mamy powody do dumy?, https://togethermagazyn.pl/polska-szkola-czy-mamy-powody-do-dumy (dostęp: 09.07.2021)

Morbitzer J.(2014). O wychowaniu wświecie nowych mediów - zarys problematyki, http://webcache.googleusercontent.com/search?q=cache:cHmHUbk8A7kJ:cejsh.icm.edu.pl/cejsh/element/bwmeta1.element.desklight-b161f80a2794-48e1-a283-49082795e2e2/c/labor_2_morbitzer.pdf+\&cd=3\&h$\mathrm{l}=\mathrm{pl} \& \mathrm{ct}=\mathrm{clnk} \& \mathrm{gl}=\mathrm{pl} \& \mathrm{client}=$ firefox-b-d (dostęp: 12.07.2021)

Ostrowska M. (2019). Jaka jest współczesna szkoła?, http://ostrowska.edu. pl/2009/02/jaka-jest-wspolczesna-szkola/ (dostęp: 10.07.2021)

Zdziebłowski Sz. (2021). Dlugotrwałe nauczanie zdalne w szkołach $i$ uczelniach źle wpływa na psychike młodych ludzi, http://naukawpolsce.pap.pl/aktualnosci/news\%2C87027\%2Cekspertka-dlugotrwale-nauczanie-zdalne-wszkolach-i-uczelniach-zle-wplywa-na (dostęp: 18.04.2021) 
